Research Article

\title{
Evaluation of Nootropic Activity of Persicaria flaccida on Cognitive Performance, Brain Antioxidant Markers and Acetylcholinesterase Activity in Rats: Implication for the Management of Alzheimer's Disease
}

\author{
Md. Sahab Uddin ${ }^{1}$, Md. Nasrullah ${ }^{1}$, Md. Sarwar Hossain ${ }^{2}$, Md. Mosiqur Rahman ${ }^{1}$, \\ Md. Shahid Sarwar ${ }^{3}$, Md. Shah Amran ${ }^{4}$, Md. Golam Sadik ${ }^{5}$, Mamunur Rashid ${ }^{1,5}$, \\ Md. Asaduzzaman ${ }^{1, *}$ \\ ${ }^{1}$ Department of Pharmacy, Southeast University, Dhaka, Bangladesh \\ ${ }^{2}$ Department of Pharmacy, State University of Bangladesh, Dhaka, Bangladesh \\ ${ }^{3}$ Department of Pharmacy, Noakhali Science and Technology University, Noakhali, Bangladesh \\ ${ }^{4}$ Department of Pharmaceutical Chemistry, Faculty of Pharmacy, University of Dhaka, Dhaka, Bangladesh \\ ${ }^{5}$ Department of Pharmacy, University of Rajshahi, Rajshahi, Bangladesh \\ Email address: \\ msu-neuropharma@hotmail.com (Md. S. Uddin), asadph14@yahoo.com (Md. Asaduzzaman) \\ ${ }^{*}$ Corresponding author
}

\section{To cite this article:}

Md. Sahab Uddin, Md. Nasrullah, Md. Sarwar Hossain, Md. Mosiqur Rahman, Md. Shahid Sarwar, Md. Shah Amran, Md. Golam Sadik, Mamunur Rashid, Md. Asaduzzaman. Evaluation of Nootropic Activity of Persicaria flaccida on Cognitive Performance, Brain Antioxidant Markers and Acetylcholinesterase Activity in Rats: Implication for the Management of Alzheimer's Disease. American Journal of Psychiatry and Neuroscience. Vol. 4, No. 2, 2016, pp. 26-37. doi: 10.11648/j.ajpn.20160402.12

Received: February 10, 2016; Accepted: April 18, 2016; Published: May 14, 2016

\begin{abstract}
Oxidative stress is the leading cause of neurodegenerative diseases, especially Alzheimer's disease (AD). The plant Persicaria flaccida $(\mathrm{PF})$ is known in Bengali as red Biskatali belongs to family Polygonaceae. Preliminary studies have shown the antioxidant, anti-inflammatory, analgesic, neuroprotective activities of Biskatali. In this consequence, methanolic extract of PF (MEPF) was selected to explore the ability of this plant to enhance cognitive functions, brain antioxidant enzymes and anti-acetylcholinesterase activity which can be used for the treatment of AD. The objective of this study was to investigate the effects of MEPF on cognitive performance, brain antioxidant enzymes and acetylcholinesterase activity in rats by using behavioral and biochemical study. Treatment with MEPF (i.e., 100 and $200 \mathrm{mg} / \mathrm{kg}$ b.w.) was investigated for 14 days in Swiss albino male rats and its effects on different types of memory were examined using Elevated Plus Maze (EPM) test, Passive Avoidance (PA) test, Morris Water Maze (MWM) test as well as level of antioxidant enzymes such as catalase (CAT), superoxide dismutase (SOD), glutathione peroxidase (GSH-Px), glutathione reductase (GSR), glutathione-S-transferase (GST) and contents of thiobarbituric acid reactive substances (TBARS) in rat brain tissue homogenates. Acetylcholinesterase (AChE) activity was determined by colorimetric method. Administration of highest dose of MEPF significantly $(\mathrm{P}<0.05, \mathrm{P}<0.01)$ decreased retention transfer latency (RTL) of rats on $7^{\text {th }}$ and $14^{\text {th }}$ day compared to the control group in EPM test. In PA test highest dose of MEPF meaningfully (P $<0.05$, $\mathrm{P}<0.01$ ) increased step-through latency (STL) of rats on $7^{\text {th }}, 12^{\text {th }}, 13^{\text {th }}$ and $14^{\text {th }}$ day with respect to control group. Both doses of MEPF markedly $(\mathrm{P}<0.01, \mathrm{P}<0.001)$ decreased escape latency $(\mathrm{EL})$, increased time spent in the target quadrant (TSTQ) and time spent in the annuli (TSA) of rats on successive days as compared to that of control group in MWM test. MEPF administration, especially highest dose significantly $(\mathrm{P}<0.05, \mathrm{P}<0.01, \mathrm{P}<0.001)$ increased the level of CAT, SOD, GSR, GST \& GSH-Px and considerably $(\mathrm{P}<0.01, \mathrm{P}<0.001)$ decreased TBARS level \& AChE activity in the brain tissue homogenates of rats compared to the control group. Behavioral and biochemical studies suggest that MEPF promotes cognitive function by improving different types of memory and reduces oxidative stress by increasing the level of brain antioxidant markers and anti-acetylcholinesterase activity. Therefore, this plant extract can be used for enhancing memory in neurodegenerative disorders like AD.
\end{abstract}


Keywords: Nootropic, Persicaria flaccida, Cognition, Brain Antioxidants Marker, Acetylcholinesterase, Alzheimer's Disease

\section{Introduction}

The most outstanding features of human being are the cognitive functions. The main cognitive functions most affected by age are learning and memory. Learning refers to the collection of new information from the surrounding environment, while memory is the ability to retention and retrieves information $[1,2]$. Cognitive function is vulnerable to a variety of neurodegenerative diseases like Alzheimer's disease (AD) [3]. $\mathrm{AD}$ is a progressive neurodegenerative disorder which is associated with the unavoidable loss of cognitive functions [4]. This disease is characterized by senile plaques, amyloid- $\beta$ (A $\beta)$ deposits and neurofibrillary tangles (NFTs) in the cerebral cortex and subcortical gray matter [5]. This is the most common dementing illness of the elderly, currently affecting approximately 5.2 million people in the United States and 30 million worldwide [6]. This value is expected to more than 100 million, in the year 2050, due to the "baby boomer" generation becoming older [7].

Oxidative stress is one of the leading causes of neurodegenerative diseases, especially AD [8]. During the metabolic process various types of free radicals are produced and living organisms have developed several defense mechanisms to protect themselves from oxidative stress. As a result, there is a balance between oxidation and anti-oxidation in our body under normal conditions. It has been shown that an imbalance between reactive oxygen species (ROS) and antioxidant factors induce cellular and molecular abnormalities in late-onset sporadic AD [9]. In the brain and blood stream of $\mathrm{AD}$ patient's atypical levels of oxidative stress have been testified [10]. The brain is more susceptible to damage from free radicals caused by oxidation processes due to high lipid content $(60 \%)$ and excessive consumption of oxygen $(20 \%)$ [11]. In addition to this the brain is especially rich in iron, which plays an important role in the generation of reactive oxygen species (ROS) in the membrane lipids consisting mainly of polyunsaturated fatty acids. Although the exact mechanisms responsible for this deleterious effect remain unclear, it is clear that oxidative stress occurs before the formation of senile plaques and NFTs both of which are neuropathological hallmarks of AD [12].

Patients affected with AD have cognitive impairment due to improper function of the central cholinergic system. Cognitive functions depend on the central cholinergic system and the activity of the AChE (acetylcholinesterase). The main indicator of $\mathrm{AD}$ is the alteration of this AChE activity [13-15]. The involvement of oxidative stress in $\mathrm{AD}$ has long been known and investigated [16]. Brain antioxidant defense enzymes such as catalase (CAT), superoxide dismutase (SOD), glutathione peroxidase (GSH-Px), glutathione reductase (GSR) and glutathione-S-transferase (GST) play an important role in preventing or slowing the progression of free radical mediated oxidative stress [17].

Mankind has been using plants as therapeutic agents for thousands of years and continues to rely on them for health care. This fact was seen from the use of natural herbs to cure disease and relieve physical sufferings. Medicinal plants are the best source of natural nootropics. The phytoconstituents of plants play an important role in the treatment of AD. Natural cognitive enhancer such as Ginkgo biloba, [18] Bacopa Monnieri [19] and Huperzia serrata [20] has been widely examined for the treatment of AD patients.

The plant Persicaria flaccida (PF) is known in Bengali as red Biskatali belongs to the family Polygonaceae has been explored for cognitive activity. The Polygonaceae comprise about 1220 species of monoecious and dioecious herbs, shrubs and small trees distributed into about 50 genera [21]. The genera, Persicaria consist of 100 species [22]. Most of the plants of the genera Persicaria possess important pharmacological effects such as anti-inflammatory, analgesic, antibacterial, antifungal and diuretic activities. Studies have shown that genera Persicaria is highly enriched in flavonoids, alkaloids, tannins, saponins and volatile constituents [23]. Plant flavonoids are polyphenolic molecules possess antioxidant, anti-inflammatory, metal-chelating [24] and anticancer properties [25]. Previous studies have shown that Biskatali (Persicaria stagnina, Persicaria hydropiper) has antioxidant, anti-inflammatory, analgesic, neuroprotective, anthelminthic and xanthine oxidase inhibitory activities [26-29]. Although PF has important medicinal values for the treatment of $\mathrm{AD}$, no studies have yet examined its anti-AD capabilities.

Therefore, the purpose of this study was to investigate the effect of methanolic extract of PF (MEPF) on learning and memory improvement in rats via tests including the Elevated Plus Maze (EPM) test, Passive Avoidance (PA) test, Morris Water Maze (MWM) test as well as the activity of antioxidant enzymes catalase (CAT), superoxide dismutase (SOD), glutathione peroxidase (GSH-Px), glutathione reductase (GSR), glutathione-S-transferase (GST), estimation of lipid peroxidation (TBARS) and acetylcholinesterase (AChE) activity in rat brain tissue homogenates.

\section{Methodology}

\subsection{Chemicals and Drug}

Acetyl thiocholine iodide (ATCI); 5,5-dithiobis-2-nitrobenzoate ion (DTNB); trisamino methane hydrochloride (Tris-HCl); bovine serum albumin (BSA); phenazinemethosulphate sodium pyrophosphate; sodium azide; reduced glutathione (GSH); ethylenediaminetetraacetic acid (EDTA); nicotinamide adenine dinucleotide phosphate (NADPH); 1-chloro-2,4-dinitrobenzene (CDNB); trichloroacetic acid (TCA) thiobarbituric acid (TBA) and 
trichloroacetic acid all were purchased from Sigma-Aldrich, USA. Unless otherwise specified, all other chemicals were of analytical grade. Donepezil hydrochloride powder was obtained from Incepta Pharmaceuticals Ltd. as gift.

\subsection{Collection, Identification, Drying and Grinding of Plant Materials}

The aerial parts of PF were collected from Brahmanbaria district, Bangladesh, in February, 2014, and identified by expert of Bangladesh National Herbarium, Mirpur, Dhaka, Bangladesh. Accession number: DACB-39528 for PF. Aerial parts of the plant were washed properly to remove dirty materials and shade dried for several days with occasional sun drying. These were then dried in an oven for $24 \mathrm{hrs}$ at considerably lower temperatures for better grinding. The dried aerial parts were ground into coarse powder by a grinding machine and stored in a glass container until extraction.

\subsection{Plants Extract Preparation}

Powdered plant materials having a weight of about $500 \mathrm{~g}$ were taken in an amber colored glass bottle and soaked in 2 liter of $98 \%$ methanol. The bottle with its contents were sealed and kept for a period of about 7 days with occasional shaking. The whole mixture was then filtered through cotton and then through Whatman No.1 filter paper. Then the filtrate was concentrated with a rotary evaporator under reduced pressure at $50^{\circ} \mathrm{C}$ temperature to afford crude extract $(12.485 \mathrm{~g})$. The crude methanolic extract was stored at $4^{\circ} \mathrm{C}$ for further tests.

\subsection{Animals}

Forty healthy Swiss albino male rats weighing 180-210 g were obtained from the animal resources division of ICDDR, $\mathrm{B}$, Dhaka, Bangladesh. The entire rats were housed three per cage placed at $25 \pm 2^{\circ} \mathrm{C}$ temperature, $60 \pm 5 \%$ relative humidity with a half day light and dark cycle. Standard food and water were supplied timely. The guide for laboratory animals of the National Institutes of Health (NIH) was used for the use and care of animals [30]. The protocol of the experiment was approved by the animal ethics committee of the Department of Pharmacy, Southeast University, Dhaka, Bangladesh.

\subsection{Administration of Drugs and Test Compounds}

Donepezil hydrochloride was used as standard for this study. A solution of donepezil hydrochloride was made by normal saline ( $\mathrm{pH} 7.4)$ and administered orally to rats. Weighed quantity of MEPF was suspended in normal saline ( $\mathrm{pH} 7.4$ ) and administered orally to rats. Based on literature searches the doses of the donepezil hydrochloride and MEPF were selected [31, 32]. Standard drug and the suspension of extract were prepared freshly every day and administered before 30 min of the experiment.

\subsection{Experimental Design}

The total duration of the study was 14 days. Rats were divided randomly into four groups with 6 rats in each as follows:

Group 1: In case of this group only standard food and water were administered to rats (Con)

Group 2: In case of this group donepezil hydrochloride at a dose of $1 \mathrm{mg} / \mathrm{kg}$ b.w. was administered to rats (Don)

Group 3: In case of this group plant extract at a dose of 100 $\mathrm{mg} / \mathrm{kg}$ b.w. was administered to rats (MEPF 100)

Group 4: In case of this group plant extract at a dose of 200 $\mathrm{mg} / \mathrm{kg}$ b.w. was administered to rats (MEPF 200)

\subsection{Acute Toxicity Study}

The guidelines of the Organisation for Economic Cooperation and Development (OECD) were used for acute toxicity study [33]. For this test rats were divided into 4 groups, with 6 rats per groups. The extracts were prepared by using normal saline and administered to rats only once at a dose of 5, 50, 300 and $2000 \mathrm{mg} / \mathrm{kg}$ b.w. Before administration of the extracts rats were fasted for 3-4 hrs, but only water was provided and after the administration food was withdrawn for 1-2 hrs. Rats were kept under observation for next $24 \mathrm{hrs}$ for any behavioral, neurological profiles and 14 days for mortality.

\subsection{Behavioral Study}

Rats were trained for behavioral study by conducting 1 week training during which they did not receive any plant extract or drug. The completely trained rats were selected for the study. Experiments were carried out in the light period between 10:00 am and 03:00 pm in a soundproof room under a natural light.

\subsubsection{Elevated Plus Maze (EPM) Test}

Cognitive behaviors of rats were assessed by using the EPM test, which measures spatial long-term memory [34]. The EPM was plus shape apparatus, made of PVC (polyvinyl chloride). It had two open arms (length, $500 \mathrm{~mm} \times$ width, $100 \mathrm{~mm}$ ) and two close arms (length, $500 \mathrm{~mm} \times$ width, 100 $\mathrm{mm} \times$ height of the side walls, $400 \mathrm{~mm}$ ), with an open roof. The arms were connected by a central square in the middle of the maze. The plus maze was elevated $500 \mathrm{~mm}$ above the floor. Two dimmed spotlights provided illumination on the floor of the enclosed and open arms of approximately 5 lux [35]. At the start of the trial the rat was placed individually at one end of an open arm facing away from the central square. The time taken by rat to move from open arm and enter into one of the closed arm with all its four legs was recorded as initial transfer latency (ITL) using a stopwatch. To become familiar with the maze, the rats were allowed to move freely in the apparatus for $30 \mathrm{sec}$ after reaching the closed arm and then returned to its home cage. Retention transfer latency (RTL) of this learned task (memory) was examined $24 \mathrm{hrs}$ after the first day trial. The duration of this test was $300 \mathrm{sec}$ [36]. After each test the apparatus was cleaned with $70 \%$ ethanol to remove any olfactory clue. In the EPM test, the measures analyzed were ITL and RTL. If the rat did not enter into one of the closed arm within $300 \mathrm{sec}$, was eliminated from the experiments [37]. 


\subsubsection{Passive Avoidance (PA) Test}

In PA test all rats were subjected for the assessment of emotional memory based on contextual fear conditioning learning and instrumental learning [38]. The EPM was box shaped apparatus having light and dark compartment (depth, $270 \mathrm{~mm} \times$ width, $370 \mathrm{~mm} \times$ height, $360 \mathrm{~mm}$ ). The separation of two distinct compartments was made by a flat-box partition, including a sliding door having $90 \mathrm{~mm}$ of diameter in the middle part. The light compartment is made of transparent PVC plates and the dark compartment is made of black PVC plates. The floor consisted of a metal grid (diameter of stainless steel bars $6.3 \mathrm{~mm}, \times$ free space between bars 11.3 $\mathrm{mm}$ ) connected to a shock generator. The shock generator was able to generate shock in the range of $0.5 \mathrm{~mA}$. In the light compartment lighting is provided by a fluorescent lamp [39]. Each test involved two separate trials, an acquisition trial and a retention trial. For the acquisition trial, the rats were initially placed in the light compartment facing the wall opposite to the guillotine door. The guillotine door was opened, after $15 \mathrm{sec}$ accommodation period. When the rats entered the dark compartment, an electrical foot shock of $0.5 \mathrm{~mA}$ was administered for $3 \mathrm{sec}$ [40]. The rat was returned back to the home cage from the apparatus $10 \mathrm{sec}$ after shock termination. The latency times, once the rats had entered the dark compartment with all its four legs were recorded as escape latency (EL) using a stopwatch. A retention trial was performed after 24, 48 and $72 \mathrm{hrs}$ following the acquisition trial, in which no shock was given when the rats entered the dark compartment and latency times to re-enter the dark chamber were measured as step-through latency (STL). The duration of this test was $300 \mathrm{sec}$ [41]. After each test the apparatus was cleaned with $70 \%$ ethanol to remove any olfactory clue. In the PA test the measures analyzed were the EL and STL. If the rat did not enter into the dark compartment within $300 \mathrm{sec}$, its STL was assigned as $300 \mathrm{sec}$ [36].

\subsubsection{Morris Water Maze (MWM) Test}

In MWM test all rats were subjected for the assessment of spatial learning and memory [41]. The MWM was tank shaped apparatus (diameter, $1700 \mathrm{~mm} \times$ depth, $450 \mathrm{~mm}$ ) made of gray polypropylene. The tank was divided into four quadrants. A submerged platform made of gray polypropylene was placed in one compartment. The diameter of the platform was 110 $\mathrm{mm}$ and height $250 \mathrm{~mm}$ (approximately $1 \mathrm{~cm}$ below the water surface). During testing, the tank was filled to a depth of $260 \mathrm{~mm}$ with water maintained at $25^{\circ} \mathrm{C}$ and the room was indirectly lighted by desk lamps directed against the walls. The water was made opaque with nontoxic white colored dye to hide the submerged platform [42]. In acquisition trial a rat was placed in the middle of a compartment of the tank, facing the wall of the tank and allowed to explore the submerged platform for $300 \mathrm{sec}$. A trial was finished as soon as the rat had mounted onto the platform. If the rat failed to find the platform within $300 \mathrm{sec}$, it was directed toward the platform. In both of this case a rat was allowed to stay on the platform for $30 \mathrm{sec}$. Each rat was subjected to four consecutive trials each day with a different starting point, in random order as given in Table 1.
Table 1. The sequence of trials during the study period of WMM test.

\begin{tabular}{lllllll}
\hline $\mathbf{1}^{\text {th }}$ Day & $\mathbf{2}^{\text {nd }}$ Day & $\mathbf{3}^{\text {rd }}$ Day & $\mathbf{4}^{\text {th }}$ Day & $\mathbf{5}^{\text {th }}$ Day & $\mathbf{6}^{\text {th }}$ Day & $\mathbf{7}^{\text {th }}$ Day \\
\hline Q1 & Q2 & Q3 & Q4 & Q1 & Q2 & Q3 \\
Q2 & Q3 & Q4 & Q1 & Q2 & Q3 & Q4 \\
Q3 & Q4 & Q1 & Q2 & Q3 & Q4 & Q1 \\
Q4 & Q1 & Q2 & Q3 & Q4 & Q1 & Q2 \\
\hline
\end{tabular}

The platform was always in the same quadrant (south). Escape latency (EL) is the time taken to find the submerged platform. The EL and time spent in the target quadrant (TSTQ) were recorded using a stopwatch. After completion of the fourth trial, the rat was gently dried with a soft cloth and kept warm under a 150-Watt bulb within the home case [43].

After the fourth trial of the last day $\left(14^{\text {th }}\right.$ day), a probe trial was given. The platform was removed and the time spent in the target quadrant (TSTQ) and all the three quadrants was measured for $60 \mathrm{sec}$. In the probe trial, all rats started from the same starting position, opposite to the quadrant (south) where the platform had been positioned during acquisition. The TSTQ and time spent in the annuli (TSA) were recorded using a stopwatch [44]. In the MWM test, for acquisition trial the measures analyzed were EL and TSTQ. For probe trial the measures analyzed were TSTQ and TSA [40, 42].

\subsection{Biochemical Study}

The rats were sacrificed under light anesthesia on $15^{\text {th }}$ day and whole brain was collected. From the entire brain tissue the cerebellum was rapidly detached and the residual brain was washed with ice-cold $0.9 \% \mathrm{NaCl}$ and ultimately each hemisphere was separated. To prepare $10 \%$ brain homogenate from one of the two hemispheres was used with the help of ice-cold phosphate buffer $(30 \mathrm{mM}, \mathrm{pH} 7.6)$ in a homogenizer. To eliminate cellular debris the homogenate was allowed to centrifuge at 20,000 RPM for $2 \mathrm{hrs}$ at $4^{\circ} \mathrm{C}$ and finally the supernatant was used for the determination of CAT, SOD, GSR, GST, GSH-Px and TBARS activity. Remaining hemispheres was homogenized $(10 \% \mathrm{w} / \mathrm{v})$ by using a glass homogenizer in ice-cold phosphate buffer $(30 \mathrm{mM}, \mathrm{pH} 7.6)$ and then allowed to centrifuge at 20,000 RPM for $2 \mathrm{hrs}$ at $4^{\circ} \mathrm{C}$ in order to get the salt soluble (SS) part. The pellets were re-extracted with an equal volume of ice-cold phosphate buffer containing $1 \%$ Triton X-100 and centrifuged at 20,000 RPM for $2 \mathrm{hrs}$ at $4^{\circ} \mathrm{C}$ to recover the detergent soluble (DS) part. From the both extraction processes supernatant was obtained and stored at $-20^{\circ} \mathrm{C}$ and used for the determination of AChE activity. By using bovine serum albumin (BSA) the protein concentration was determined [45].

\subsubsection{Catalase (CAT) Assay}

The CAT activity was determined according the method of Chance and Maehly with some modification [46]. The reaction mixture of CAT activities was consisted of $2.5 \mathrm{ml}$ of $50 \mathrm{mM}$ phosphate buffer having $\mathrm{pH} 5.0,0.4 \mathrm{ml}$ of $5.9 \mathrm{mM}$ $\mathrm{H}_{2} \mathrm{O}_{2}$ and $0.1 \mathrm{ml}$ of $10 \%$ brain homogenate. The total volume of this reaction mixture was $3.0 \mathrm{ml}$. After $1 \mathrm{~min}$ the changes in absorbance of the reaction mixture were determined at $240 \mathrm{~nm}$. In case of this method one unit of CAT activity was defined as an absorbance change of 0.01 as $\mathrm{U} / \mathrm{min}$. 


\subsubsection{Super Oxide Dismutase (SOD) Assay}

The SOD activity was determined according to the method of Kakkar et al., [47]. The reaction mixture contained $0.1 \mathrm{ml}$ of $186 \mu \mathrm{M}$ phenazinemethosulphate, $1.2 \mathrm{ml}$ of $0.052 \mathrm{mM}$ sodium pyrophosphate buffer having $\mathrm{pH} 7.0,0.3 \mathrm{ml}$ of supernatant after centrifugation $(1500 \times \mathrm{g}, 10 \mathrm{~min}$ followed by $10,000 \times \mathrm{g}, 15$ $\min$ ) of $10 \%$ brain homogenate was added to the reaction mixture. The total volume of this reaction mixture was $1.6 \mathrm{ml}$. In order to start enzyme reaction $0.2 \mathrm{ml}$ of $780 \mu \mathrm{M}$ NADH was added to the reaction mixture. After 1 min enzyme reaction was stopped by adding $1 \mathrm{ml}$ of glacial acetic acid. The SOD activity was measured at $560 \mathrm{~nm}$ and expressed as U/mg protein.

\subsubsection{Glutathione Reductase (GSR) Assay}

The GSR activity was determined according to the method of Carlberg and Mannervik [48]. The reaction mixture contained $1.65 \mathrm{ml}$ of $0.1 \mathrm{M}$ phosphate buffer having $\mathrm{pH} 7.6$, $0.1 \mathrm{ml}$ of $0.5 \mathrm{mM}$ EDTA, $0.1 \mathrm{ml}$ of $0.1 \mathrm{mM} \mathrm{NADPH}, 0.05 \mathrm{ml}$ of $1 \mathrm{mM}$ oxidized GSH and $0.1 \mathrm{ml}$ of $10 \%$ brain homogenate. The total volume of this reaction mixture was $2.0 \mathrm{ml}$. The changes in absorbance of the reaction mixture (i.e., disappearance of $\mathrm{NADPH}$ ) at $25^{\circ} \mathrm{C}$ were determined at $340 \mathrm{~nm}$ and expressed as nM NADPH oxidized $/ \mathrm{min} / \mathrm{mg}$ protein using a molar extinction coefficient of $6.22 \times 10^{3} \mathrm{M}^{-1} \mathrm{~cm}^{-1}$.

\subsubsection{Glutathione-S-transferase (GST) Assay}

The GST activity was determined according to the method of Habig et al., [49]. The reaction mixture of GST activities was consisted of $1.475 \mathrm{ml}$ of $0.1 \mathrm{M}$ phosphate buffer having $\mathrm{pH} 6.5$, $0.025 \mathrm{ml}$ of $1 \mathrm{mM} \mathrm{CDNB}, 0.2 \mathrm{ml}$ of $1 \mathrm{mM}$ reduced $\mathrm{GSH}$ and $0.3 \mathrm{ml}$ of $10 \%$ brain homogenate. The total volume of this reaction mixture was $2.0 \mathrm{ml}$. The changes in absorbance of the reaction mixture were determined at $340 \mathrm{~nm}$ and expressed as $\mathrm{nM}$ CDNB conjugate formed $/ \mathrm{min} / \mathrm{mg}$ protein using a molar extinction coefficient of $9.6 \times 10^{3} \mathrm{M}^{-1} \mathrm{~cm}^{-1}$.

\subsubsection{Glutathione Peroxidase (GSH-Px) Assay}

The GSH-Px activity was determined according to the method of Mohandas et al., [50]. The reaction mixture contained $1.49 \mathrm{ml}$ of $0.1 \mathrm{M}$ phosphate buffer having $\mathrm{pH} 7.4,0.1$ $\mathrm{ml}$ of $1 \mathrm{mM}$ sodium azide, $0.05 \mathrm{ml}$ of $1 \mathrm{IU} / \mathrm{ml}$ glutathione reductase, $0.05 \mathrm{ml}$ of $1 \mathrm{mM} \mathrm{GSH}, 0.1 \mathrm{ml}$ of $1 \mathrm{mM}$ EDTA, 0.1 $\mathrm{ml}$ of $0.2 \mathrm{mMNADPH}, 0.01 \mathrm{ml}$ of $0.25 \mathrm{mM} \mathrm{H}_{2} \mathrm{O}_{2}$ and $0.1 \mathrm{ml}$ of $10 \%$ brain homogenate. The total volume of this reaction mixture was $2.0 \mathrm{ml}$. The changes in absorbance of the reaction mixture (disappearance of NADPH) at $25^{\circ} \mathrm{C}$ were determined at $340 \mathrm{~nm}$ and expressed as nM NADPH oxidized $/ \mathrm{min} / \mathrm{mg}$ protein using a molar extinction coefficient of $6.22 \times 10^{3} \mathrm{M}^{-1} \mathrm{~cm}^{-1}$.

\subsubsection{Lipid Peroxidation (TBARS) Assay}

The TBARS activity was determined according to the method of Iqbal et al., [51]. The reaction mixture of thiobarbituric acid reactive species (TBARS) activities was consisted of $0.58 \mathrm{ml}$ of $0.1 \mathrm{M}$ phosphate buffer having $\mathrm{pH} 7.4$, $0.2 \mathrm{ml}$ of $100 \mathrm{mM}$ ascorbic acid, $0.02 \mathrm{ml}$ of $100 \mathrm{mM}$ ferric chloride and $0.2 \mathrm{ml}$ of $10 \%$ brain homogenate. The total volume of this reaction mixture was $1.0 \mathrm{ml}$. The reaction mixture was incubated in a shaking water bath for $1 \mathrm{hrs}$ at $37^{\circ} \mathrm{C}$. The reaction was stopped by the addition of $1.0 \mathrm{ml}$ of $10 \%$ TCA. After addition of $1.0 \mathrm{ml} 0.67 \% \mathrm{TBA}$, all the test tubes were boiled in a water-bath for $20 \mathrm{~min}$. Then the test tubes were shifted to crushed ice-bath before centrifuging $(2500 \times \mathrm{g}, 10 \mathrm{~min})$. The amount of TBARS formed in each of the samples was assessed by measuring the optical density of the supernatant at $535 \mathrm{~nm}$ using spectrophotometer against a blank solution contain all the reagents except extract or standard. The TBARS activity was expressed as $\mathrm{nM}$ TBARS $/ \mathrm{min} / \mathrm{mg}$ protein at $37^{\circ} \mathrm{C}$ using a molar extinction coefficient of $1.56 \times 10^{5} \mathrm{M}^{-1} \mathrm{~cm}^{-1}$.

\subsubsection{Acetylcholinesterase (AChE) Assay}

Acetylcholinesterase (AChE) activity was determined using the colorimetric assay of Ellman et al., [52]. Briefly, in the 96 well plates, $25 \mu \mathrm{l}$ of $15 \mathrm{mM}$ ATCI, $75 \mu \mathrm{l}$ of 3 DTNB and $75 \mu \mathrm{l}$ of $50 \mathrm{mM}$ Tris- $\mathrm{HCl}$ having $\mathrm{pH} 8.0$, containing $0.1 \%$ BSA, were added and absorbance was read at $405 \mathrm{~nm}$ after $5 \mathrm{~min}$ incubation at room temperature. Any increase in absorbance due to the spontaneous hydrolysis of the substrate was corrected by subtracting the rate of the reaction before adding the enzyme. Then $25 \mu \mathrm{l}$ of brain homogenates (SS and DS fraction) was added and the absorbance was read again after 5 min of incubation at $25^{\circ} \mathrm{C}$ temperature. The AChE activity was expressed as $\mathrm{M} / \mathrm{min} / \mathrm{g}$ protein.

\subsection{Statistical Analysis}

Results were expressed as mean \pm SEM. The results were analyzed with one-way analysis of variance (ANOVA) followed by Turkey's post hoc test for behavioral studies and in case of biochemical studies the least significant difference (LSD) was determined using post hoc testing for inter group comparisons at a probability level of $0.05 \%$ and $0.01 \%$. SPSS 14.0 (Chicago, IL, USA) and MS Excel 2010 (Roselle, IL, USA) was used for the statistical and graphical evaluations. A probability of $\mathrm{P}<0.05$ was considered as statistically significant compared to control group.

\section{Results}

\subsection{Determination of Acute Toxicity}

MEPF at a dose of $2000 \mathrm{mg} / \mathrm{kg}$ b.w. had no adverse effect on the behavioral, motor and neuronal responses of the tested rats up to 14 days of observation. Physical observations indicated no signs of changes in the skin, fur, eyes so the extracts were considered safe.

\subsection{Effect of MEPF on ITL and RTL of Rats Using EPM Test}

The ITL was measured on $6^{\text {th }}$ and $13^{\text {th }}$ day and RTL was measured on $7^{\text {th }}$ and $14^{\text {th }}$ day (after 24 hrs of ITL). Administration of MEPF decreased the RTL with respect to ITL in a dose-dependent mode. In rats, administration of MEPF on successive days considerably decreased RTL with respect to ITL as compared to non-treated rats, thus showed significant memory enhancing activity. The highest dose of MEPF $(200 \mathrm{mg} / \mathrm{kg}$ b.w. $)$ markedly $(\mathrm{P}<0.05, \mathrm{P}<0.01)$ 
decreased RTL with respect to ITL of rats as compared to that of vehicle treated control rats (Figure 1). The percent retention of memory was calculated as inflexion ratio (IR). Increase in IR after 24 hrs indicated improved retention of learning task specified in Figure 2.

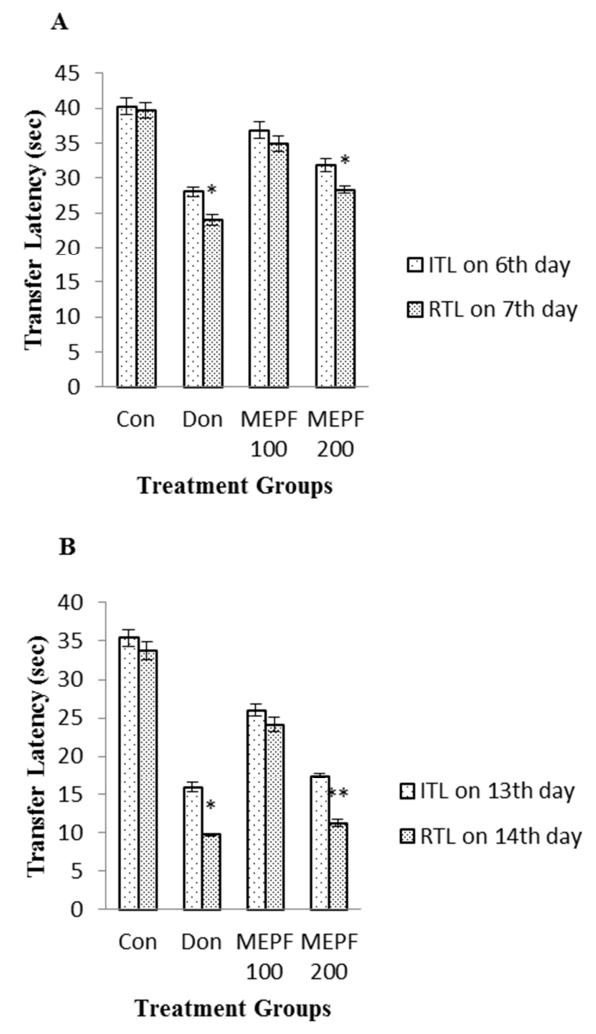

Figure 1. Effect of MEPF on ITL and RTL of rats using EPM test. Values expressed are mean $\pm \operatorname{SEM}(n=6 /$ group $)$. A. Initial and retention transfer latency on $6^{\text {th }}$ and $7^{\text {th }}$ day respectively, B. Initial and retention transfer latency on $13^{\text {th }}$ and $14^{\text {th }}$ day respectively.

$* \mathrm{P}<0.05,{ }^{*} \mathrm{P}<0.01$ significant difference from the control group

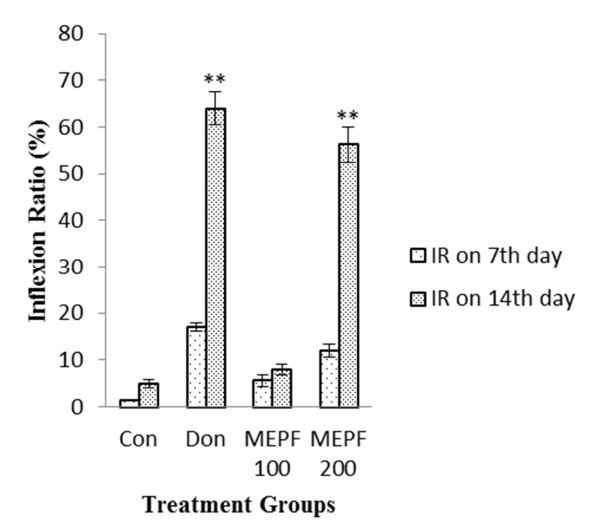

Figure 2. Effect of MEPF on IR of rats using EPM test. Values expressed are mean $\pm \operatorname{SEM}(n=6 /$ group $)$.

${ }^{* *} \mathrm{P}<0.01$ significant difference from the control group

\subsection{Effect of MEPF on EL and STL of Rats Using PA Test}

The EL was measured on $6^{\text {th }}$ and $11^{\text {th }}$ day and STL was measured on $7^{\text {th }}$, and $12^{\text {th }}, 13^{\text {th }}, 14^{\text {th }}$ day (after 24,48 and 72 hrs of EL) respectively. Administration of MEPF increased the STL in a dose-dependent mode. Among two doses the highest dose of MEPF (200 mg/kg b.w.) markedly $(\mathrm{P}<0.05, \mathrm{P}<0.01)$ increased STL of rats as compared to that of vehicle treated control rats. The value of STL was greater on $12^{\text {th }}, 13^{\text {th }}$ and $14^{\text {th }}$ day respectively, than the $7^{\text {th }}$ day STL displayed in Figure 3. The percent retention of memory was calculated as inflexion ratio (IR). Increase in IR after 24, 48 and $72 \mathrm{hrs}$ respectively indicated improved retention of learning task (Figure 4).
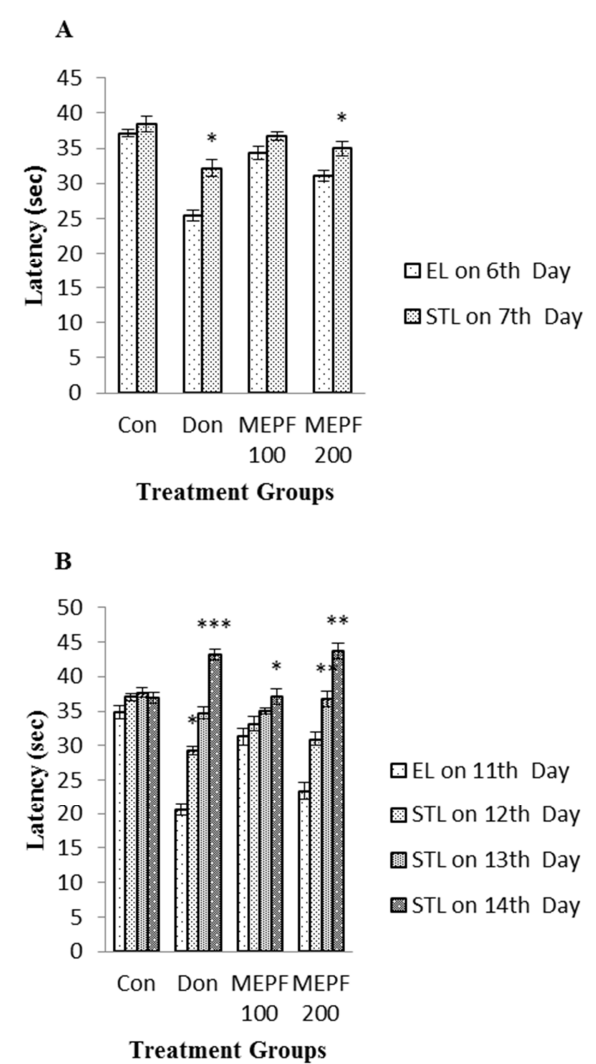

Figure 3. Effect of MEPF on EL and STL of rats using PA test. Values expressed are mean $\pm S E M(n=6 / g r o u p)$. A. Escape and step-through latency on $6^{\text {th }}$ and $7^{\text {th }}$ day respectively, B. Escape and step-through latency on 11 th and $12^{\text {th }}, 13^{\text {th }}, 14^{\text {th }}$ day respectively.

$* \mathrm{P}<0.05, * * \mathrm{P}<0.01, * * * \mathrm{P}<0.001$ significant difference from the control group

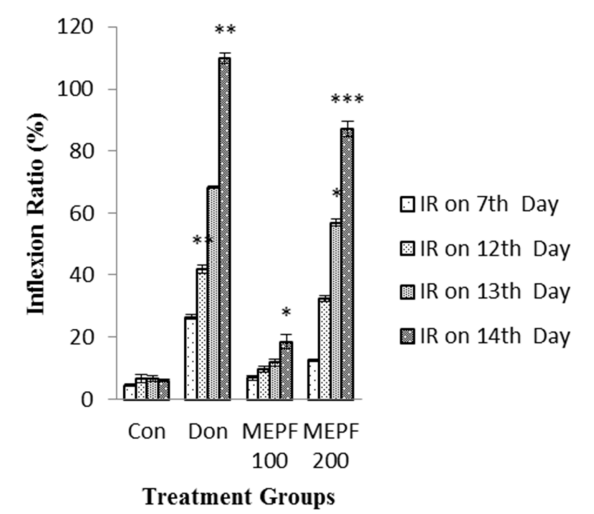

Figure 4. Effect of MEPF on IR of rats using PA test. Values expressed are mean $\pm \operatorname{SEM}(n=6 /$ group $)$.

$* \mathrm{P}<0.05, * * \mathrm{P}<0.01, * * * \mathrm{P}<0.001$ significant difference from the control group 


\subsection{Effect of MEPF on EL, TSTQ and TSA of Rats Using MWM Test}

The EL and TSTQ for acquisition trial was measured on $5^{\text {th }}$, $10^{\text {th }}$ and $14^{\text {th }}$ day. Administration of MEPF decreased the EL and increased the TSTQ in a dose-dependent mode. The highest dose of MEPF ( $200 \mathrm{mg} / \mathrm{kg}$ b.w.) markedly ( $\mathrm{P}<0.01, \mathrm{P}$ $<0.001)$ decreased EL and increased TSTQ of rats as compared to that of vehicle treated control rats (Figure 5, Figure 6). The TSTQ and TSA for probe trial were measured on $14^{\text {th }}$ day after completion of acquisition trial. Administration of MEPF increased the TSTQ and TSA in a dose-dependent mode. Like acquisition trial both doses of the MEPF extract markedly $(\mathrm{P}<0.01, \mathrm{P}<0.001)$ increased TSTQ and TSA of rats as compared to that of vehicle treated control rats, thus showed significant improvement of learning and memory given in Figure 7.

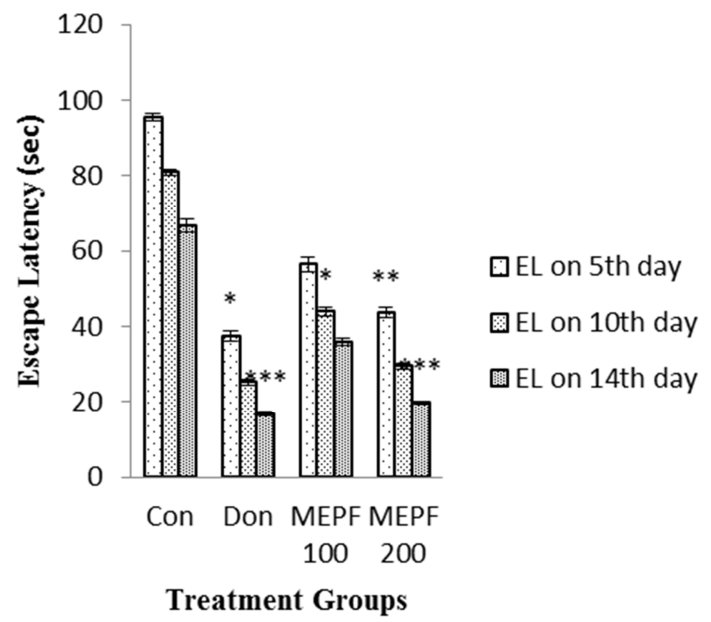

Figure 5. Effect of MEPF on EL of rat for acquisition trial using MWM test. Values expressed are mean $\pm \operatorname{SEM}(n=6 /$ group $)$.

${ }^{*} \mathrm{P}<0.05,{ }^{* *} \mathrm{P}<0.01, * * * \mathrm{P}<0.001$ significant difference from the control group

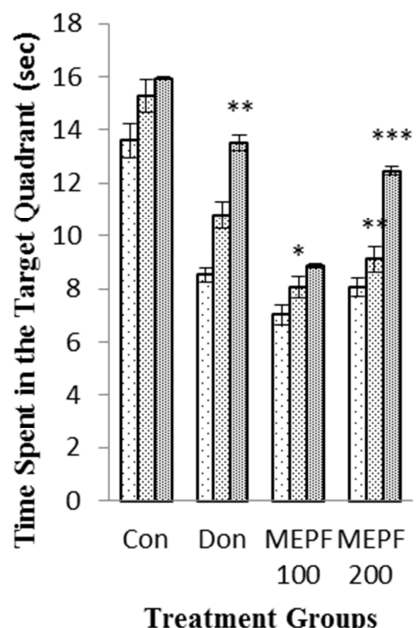

$\square$ TSTQ on 5th day

⿴囗十 TSTQ on 10th day

GTSTQ on 14th day

Figure 6. Effect of MEPF on TSTQ of rat for acquisition trial using $M W M$ test. Values expressed are mean \pm SEM ( $n=6 /$ group $)$.

$* \mathrm{P}<0.05, * * \mathrm{P}<0.01, * * * \mathrm{P}<0.001$ significant difference from the control group
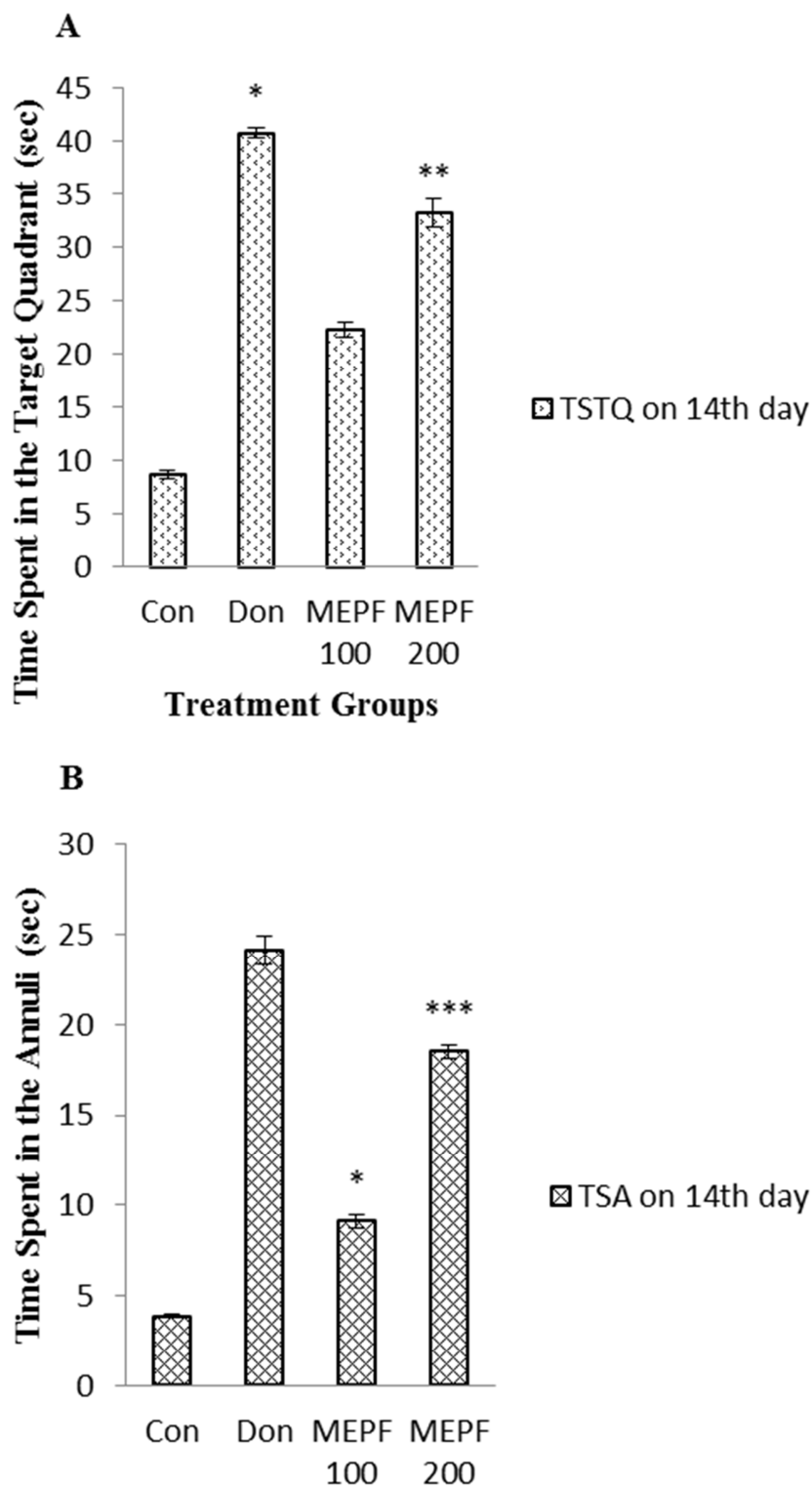

Treatment Groups

Figure 7. Effect of MEPF on TSTQ and TSA of rat for probe trial using $M W M$ test. Values expressed are mean $\pm S E M(n=6 /$ group $)$. A. Time spent in the target quadrant on $14^{\text {th }}$ day, B. Time spent in the annuli on $14^{\text {th }}$ day.

$* \mathrm{P}<0.05, * * \mathrm{P}<0.01, * * * \mathrm{P}<0.001$ significant difference from the control group

\subsection{Effect of MEPF on Oxidative Status in Rat's Brain}

Alteration in the activity of CAT, SOD, GSR, GST, GSH-Px and TBARS are shown with administration of MEPF in rats in a dose-dependent mode represented in Table 2. Administration of MEPF altered the concentration of CAT, SOD, GSR, GST, GSH-Px and TBARS. In particular, administration of highest dose of MEPF (200 mg/kg b.w.) markedly $(\mathrm{P}<0.05 \mathrm{P}<0.01, \mathrm{P}<0.001)$ increased the activities of CAT, SOD, GSR, GST, GSH-Px while significantly (P < 0.01 ) reduced the concentration of TBARS (MDA) in the brain tissue of rats to that of vehicle treated control rats. 
Table 2. Effect of donepezil hydrochloride and MEPF on biochemical parameters of rat brain antioxidant defense system.

\begin{tabular}{lllllll}
\hline Treatment & $\begin{array}{l}\text { CAT } \\
\text { (U/min) }\end{array}$ & $\begin{array}{l}\text { SOD (U/mg } \\
\text { protein) }\end{array}$ & $\begin{array}{l}\text { GSR (nM/min/mg } \\
\text { protein) }\end{array}$ & $\begin{array}{l}\text { GST (nM/min/mg } \\
\text { protein) }\end{array}$ & $\begin{array}{l}\text { GSH-Px (nM/min/mg } \\
\text { protein) }\end{array}$ & $\begin{array}{l}\text { TBARS (nM/min/mg } \\
\text { protein) }\end{array}$ \\
\hline Con & $8.09 \pm 1.82$ & $8.97 \pm 1.01$ & $123.80 \pm 1.08$ & $127.36 \pm 0.98$ & $35.75 \pm 0.83$ & $183.07 \pm 5.03$ \\
Don & $17.54 \pm 1.23$ & $22.57 \pm 1.01$ & $249.73 \pm 1.01$ & $183.47 \pm 1.39$ & $75.12 \pm 1.16$ & $162.41 \pm 4.23$ \\
MEPF 100 & $13.01 \pm 1.49^{*}$ & $15.23 \pm 1.20$ & $174.32 \pm 0.72^{*}$ & $152.57 \pm 0.82$ & $41.29 \pm 0.99^{*}$ & $172.53 \pm 4.48^{*}$ \\
MEPF 200 & $15.45 \pm 1.35^{* * *}$ & $17.93 \pm 1.07^{* *}$ & $206.16 \pm 0.84^{*}$ & $174.49 \pm 0.79^{* *}$ & $62.56 \pm 0.85^{* *}$ & $167.05 \pm 4.820^{* *}$ \\
\hline
\end{tabular}

The rats brain biochemical parameters are expressed as mean \pm SEM values $(n=6 /$ group$)$.

$* \mathrm{P}<0.05,{ }^{*} \mathrm{P}<0.01,{ }^{* * *} \mathrm{P}<0.001$ significant difference from the control group

\subsection{Effect of MEPF on AChE Activity in Rat's Brain}

Administration of MEPF significantly decreases in AChE activity in both salt soluble (SS) and detergent soluble (DS) fractions of brain tissue of rats in a dose-dependent mode as compared to non-treated rats. The highest dose of MEPF (200 $\mathrm{mg} / \mathrm{kg}$ b.w.) markedly $(\mathrm{P}<0.001)$ decreased AChE activity in SS and DS homogenate of rat's brain tissue as compared to that of vehicle treated control rats (Table 3 ).

Table 3. Effect of donepezil hydrochloride and MEPF on AChE activity in rat brain.

\begin{tabular}{|c|c|c|}
\hline Treatment & $\begin{array}{l}\mathrm{SS} A C h E(M / \mathrm{min} / \mathrm{g} \text { of } \\
\text { protein) }\end{array}$ & $\begin{array}{l}\text { DS AChE }(M / \mathrm{min} / \mathrm{g} \text { of } \\
\text { protein) }\end{array}$ \\
\hline Con & $0.178 \pm 0.004$ & $0.889 \pm 0.026$ \\
\hline Don & $0.102 \pm 0.003 * *$ & $0.329 \pm 0.010 * * *$ \\
\hline MEPF 100 & $0.133 \pm 0.003$ & $0.730 \pm 0.025^{*}$ \\
\hline MEPF 200 & $0.114 \pm 0.003 * * *$ & $0.474 \pm 0.013 * * *$ \\
\hline
\end{tabular}

The AChE activity for each group are expressed as mean \pm SEM values $(n=$ $6 /$ group).

$* \mathrm{P}<0.05, * * \mathrm{P}<0.01, * * * \mathrm{P}<0.001$ significant difference from the control group

\section{Discussion}

In this study, it was explored that administration of MEPF for 14 successive days showed better memory enhancing effect in rats. This is the first study showing memory enhancing activity of PF extracts in rats. EPM, PA and MWM tests were employed as behavioral models for evaluation of learning and memory. The antioxidant potentiality of the plant was determined by biochemical studies such as CAT, SOD, GSR, GST, GSH-Px, TBARS and AChE assay. In fact, these prototypes are extensively used for evaluating the effect of unknown plants/drugs on learning and memory [34].

EPM test is one of the behavioral tests for studying spatial long term memory. The brain tonic activity of MEPF was evaluated by EPM test. Parameters that were investigated in this test were ITL and RTL. The time spent by the rat to move from the open to the closed arm in this test is recorded as ITL. The retention of learning task was studied after $24 \mathrm{hrs}$ as RTL. In EPM test, a decrease in RTL on $7^{\text {th }}$ and $14^{\text {th }}$ day with respect to ITL on $6^{\text {th }}$ and $13^{\text {th }}$ day (after $24 \mathrm{hrs}$ of ITL) indicated improvement of spatial long-term memory of rats as compared to control rats. Bhaskar et al., in the study on Eclipta alba in rats reported significant improvement in learning and memory in EPM test [53]. PA test was performed to access learning and memory function based on the natural leaning of rats formed after an aversive stimulus. The latency times to re-enter the dark chamber were measured as STL in this test [40]. In PA test an increase in STL on $7^{\text {th }}$ (after $24 \mathrm{hrs}$ of EL) and $12^{\text {th }}, 13^{\text {th }}$, $14^{\text {th }}$ day (after 24, 48 and 72 hrs of EL) after the acquisition trial indicated improvement of learning and memory of rats as compared to control rats. In the study on Loranthus parasiticus on scopolamine-induced memory impairment in mice by Weon et al., stated increased latency time in this test [54]. MWM test is widely used behavioral tests for studying hippocampus-dependent spatial memory and leaning. This test was designed to measure effect of MEPF on cognitive performance of rats. Parameters include EL, TSTQ and TSA were investigated in this test and these parameters represent learning and memory enhancing effect of rats. In MWM test, for standard acquisition trial a decrease in EL \& increase in TSTQ on $5^{\text {th }}, 10^{\text {th }}$ and $14^{\text {th }}$ day and for probe trial an increase in TSTQ \& TSA on $14^{\text {th }}$ day indicated improvement of spatial learning and memory of rats as compared to control rats. In the study on Ziziphus jujube against ethanol-induced hippocampal oxidative stress and spatial memory impairment in rats similar findings were reported by Taati et al., [43].

The results suggested that out of the two effective doses of MEPF (100 mg and $200 \mathrm{mg} / \mathrm{kg}$ b.w.) higher dose $(200 \mathrm{mg} / \mathrm{kg}$ b.w.) produced superior nootropic effects in rats as compared to vehicle treated control rats.

SOD are group of metalloenzymes that protects oxygen-metabolizing cells and repairs cells damage done to them by superoxide free-radicals [55]. It acts as both an antioxidant and anti-inflammatory in addition protects oxygen-metabolizing cells against the harmful effects of superoxide free-radicals [56]. Studies have shown that SOD catalyzes the breakdown of the superoxide $\left(\mathrm{O}_{2}^{-} \cdot\right)$ radical into molecular oxygen $\left(\mathrm{O}_{2}\right)$ and hydrogen peroxide $\left(\mathrm{H}_{2} \mathrm{O}_{2}\right)$ leading to reduce the toxic effects. This generated $\mathrm{H}_{2} \mathrm{O}_{2}$ is less damaging, although the catalase and gluthatione peroxidase systems can neutralize the $\mathrm{H}_{2} \mathrm{O}_{2}$ by converting it to $\mathrm{H}_{2} \mathrm{O}$ and $\mathrm{O}_{2}$ [57]. CAT is a glycoprotein present in the antioxidant defense system of all cells that protects the cell from oxidative damage done by ROS [54]. It catalyzes the breakdown of $\mathrm{H}_{2} \mathrm{O}_{2}$ to $\mathrm{H}_{2} \mathrm{O}$ and $\mathrm{O}_{2}$ and protects the cell from highly reactive hydroxyl radicals. Furthermore, SOD and CAT are an important antioxidant defense in nearly all living cells exposed to oxidative stress, thus increased longevity of lifespan [58]. GSR and GST are principal antioxidant enzymes because they are involved in the reduction of oxidative damage caused by ROS [59]. GSR is a homodimeric flavoprotein that catalyzes the reduction of glutathione 
disulfide (GSSG) to the sulfhydryl form glutathione (GSH). Generated GSH is responsible for blocking oxidative stress and maintaining the reducing environment of the cell and in this way it provides the first line defense to the body. GSH is an essential component of the body's natural defense system and often referred to as the body's master antioxidant. It can act as a scavenger of hydroxyl radicals, singlet oxygen, and various electrophilic compounds [60]. Antioxidant dimeric enzyme GST catalyzes the nucleophilic attack by GSH on electrophilic compounds and toxic substrates, thereby preventing oxidative damage [61]. Like other antioxidant enzyme, GSH-Px is another antioxidant enzyme whose main function is to protect the cell from oxidative damage and thus prevent the formation of reactive free radicals. It catalyses the reduction of $\mathrm{H}_{2} \mathrm{O}_{2}$ to $\mathrm{H}_{2} \mathrm{O}$ by reacting with glutathione and converts it to oxidized glutathione. This generated GSSG is reduced to glutathione by GSR [62].

Lipid molecules react with oxygen free radicals resulting in the formation of lipid peroxides, which lead to the formation of TBARS. This generated TBARS is highly reactive and cause damage to cell membranes and to the cell itself [63]. Lipid peroxidation is a chain reaction initiated by the hydrogen abstraction or addition of oxygen radical, resulting in the oxidative damage of polyunsaturated fatty acids (PUFA), once initiated can be amplified by self-propagation [64]. About $1 \%$ of the total oxygen uptake by cells, organs and bodies in taken up by the reactions of lipid peroxidation, which is highly evident in several neurodegenerative diseases especially AD [65].

Antioxidant enzymes such as CAT, SOD, GSR, GST and GSH-Px are involved in the reduction of oxidative stress (TBARS) and their alteration are a strong link with AD.

Acetylcholine (ACh) is a neurotransmitter found in the synapses of the cerebral cortex. ACh is rapidly degraded by $\mathrm{AChE}$ enzyme and this enzyme is found in elevated level in case of AD [13-15]. The results of this study exposed that MEPF administration in rat's markedly decreased brain AChE activity. In the study on effects of Sonchus asper on brain antioxidant markers, cognitive performance and AChE activity of rats by Khan RA et al., showed that this plant extracts have beneficial for improving the learning ability and antioxidant potential [66]. For the study of Launaea procumbens on brain antioxidant enzymes and cognitive performance of rat by Khan RA also reported alike results [67].

The results suggested that administration of MEPF (100 mg and $200 \mathrm{mg} / \mathrm{kg}$ b.w.) especially higher dose (200 mg/kg b.w.) for 14 days increased the level of these antioxidant enzymes and showing protection against oxidative damage caused by free radicals. So it was clear that administration of MEPF in healthy rat reduced brain oxidative damage increased the level of antioxidant enzymes as well as decreased TBARS level and AChE activity.

The above behavioral and biochemical results suggest that MEPF has nootropic activity and gifted to improve cognitive functions and brain antioxidant markers as well as anti-acetylcholinesterase activity.

\section{Conclusion}

From the present study, it is clearly demonstrated that MEPF has nootropic activity and showed significant beneficial effects for improving the learning, memory as well as antioxidant potential. As a result this plant extracts can be used for enhancing memory in neurodegenerative disorders especially Alzheimer's disease. There is great possibility of presence of promising compound in this plant extracts. However, further studies will be necessary to characterize the active principles.

\section{Abbreviations}

AD: Alzheimer's disease; PF: Persicaria flaccida; MEPF: Methanolic extract of Persicaria flaccida; EPM: Elevated plus maze; PA: Passive avoidance; MWM: Morris water maze; CAT: Catalase; SOD: Superoxide dismutase; GSR: Glutathione reductase; GST: Glutathione-S-transferase; GSH-Px: Glutathione peroxidase; TBARS: Thiobarbituric acid reactive species; MDA: Malondialdehyde; AChE: Acetylcholinesterase; NIH: National Institutes of Health; ITL: Initial transfer latency, RTL: Retention transfer latency; STL: Step-through latency; EL: Escape latency; TSTQ: Time spent in the target quadrant; TSA: Time spent in the annuli; $A \beta$ : Amyloid- $\beta$; NFTs: Neurofibrillary tangles; ATCI: Acetyl thiocholine iodide; DTNB: 5,5 dithiobis-2-nitrobenzoate ion; Tris-HCl: Trisfamino methane hydrochloride; BSA: Bovine serum albumin; GSH: Glutathione; EDTA: Ethylenediaminetetraacetic acid; NADPH: Nicotinamide adenine dinucleotide phosphate; CDNB: 1-chloro-2,4-dinitrobenzene; TCA: Trichloroacetic acid; TBA: Thiobarbituric acid; SS: Salt soluble, DS: Detergent soluble.

\section{Ethical Approval}

The protocol of the experiment was approved by the animal ethics committee of the Department of Pharmacy, Southeast University, Dhaka, Bangladesh. The use and care of animals was performed as per the guide for NIH.

\section{Author's Contribution}

This work was carried out in collaboration among all authors. MSU and MN performed the laboratory experiments. MSH and MMR helped for statistical analysis and interpretation of data. MSU, MSA and MGS participated to prepare the manuscript. MSS revised the final manuscript. MR provided all supports to perform the tests. MA designed and supervised the study. All authors read and approved the final manuscript.

\section{Authors' Information}

${ }^{1}$ Department of Pharmacy, Southeast University, Dhaka-1213, Bangladesh. ${ }^{2}$ Department of Pharmacy, State University of Bangladesh, Dhaka-1205, Bangladesh. 
${ }^{3}$ Department of Pharmacy, Noakhali Science and Technology University, Noakhali-3814, Bangladesh. ${ }^{4}$ Department of Pharmaceutical Chemistry, Faculty of Pharmacy, University of Dhaka, Dhaka-1000, Bangladesh. ${ }^{5}$ Department of Pharmacy, University of Rajshahi, Rajshahi-6205, Bangladesh.

\section{Acknowledgments}

The authors wish to thank the Department of Pharmacy, Southeast University, Dhaka, Bangladesh for providing financial support and research facilities.

\section{Conflict of Interests}

The authors have declared no conflict of interests with the content of the article.

\section{References}

[1] A. Arzi, N. S. Karampour, M. Abolzadeh, M. Salahcheh. "Effect of quercetin on retention and retrieval of memory in young and aged mice". Res J Pharma Bio Che Sci, 2015 6: 968-969.

[2] D. R. Riddle. "Brain aging: models, methods, and mechanisms". 1st ed, USA: CRC Press, 2007.

[3] A Bhattacharjee, S. C. Shashidhara, S. Saha. "Nootropic activity of Crataeva nurvala buch-ham against scopolamine induced cognitive impairment". EXCLI Journal, 2015; 14: 335.

[4] M. W. Weiner, D. P. Veitch, P. S. Aisen, L. A. Beckett, N. J. Cairns, R. C. Green, et al., "The Alzheimer's disease neuroimaging initiative: a review of papers published since its inception". Alzheimer's Demen, 2012; 8: 1-68.

[5] M. Asaduzzaman, M. J. Uddin, M. A. Kader, A. H. M. K. Alam, A. A. Rahman, M. Rashid. "In vitro acetylcholinesterase inhibitory activity and the antioxidant properties of Aegle marmelos leaf extract: implications for the treatment of Alzheimer's disease". Psychogeri, 2014; 14: 1-10.

[6] R. Yaari R, J. Corey-Bloom. "Alzheimer's disease”. Sem Neurol, 2007; 27: 32-41.

[7] Wimo, B. Winblad, H. Aguero-Torres, E. Von Strauss. "The magnitude of dementia occurrence in the world". Alzheimer's Dis Asso Disor, 2003; 17: 63-67.

[8] R. Sultana, D. A. Butterfield. "Role of oxidative stress in the progression of Alzheimer's disease". J Bio Chem, 2007; 282: 6984-6991.

[9] B. Kuhla, C. Haase, K. Flach, H. J. Luth, T. Arendt, G. Munch. "Effect of pseudophosphorylation and cross linking by lipid peroxidation and advanced glycation end product precursors on tau aggregation and filament formation". J Biological Che, 2007; 282: 6984-6991.

[10] M. Sarter, J. P. Bruno. "Cognitive functions of cortical acetylcholine: toward a unifying hypothesis". Brain Res Rev, 1997; 23: 28-46.

[11] G. Zimmerman, H. Soreq. "Termination and beyond: acetylcholinesterase as a modulator of synaptic transmission". Cell Tissue Res, 2006; 326: 655-669.
[12] R. M. Lane, S. G. Potkin, A. Enz. "Targeting acetylcholinesterase and butyrylcholinesterase in dementia". Intl J Neuropsycopharmacol, 2006; 9: 101-124.

[13] Y. T. Chang, W. N. Chang, N. W. Tsai, C. C. Huang, C. T. Kung, Y. J. Su. "The roles of biomarkers of oxidative stress and antioxidant in Alzheimer's Disease: a systematic review". BioMed Res Inter, 2014; 1-11.

[14] D. J. Bonda, X. Wang, G. Perry, A. Nunomura, M. Tabaton, X. Zhu, et al., "Oxidative stress in Alzheimer disease: a possibility for prevention”. Neuropharmaco, 2010; 59: 290-294.

[15] L. Migliore, I. Fontana, F. Trippi, R. Colognato, F. Coppede, G. Tognoni, et al., "Oxidative DNA damage in peripheral leukocytes of mild cognitive impairment and AD patients". Neurobiol Agi, 2005; 26: 567-573.

[16] C. Behl, "Oxidative stress in Alzheimer's disease: implications for prevention and therapy". Subcel Bioche, 2005; 38: 65-78.

[17] J. Sharma, R. Chawla, R. Kumar, A. Sharma, R. K. Sharma, R. Arora. "Camellia sinensis as a safe neuroprotective radiation counter measure agent”. Int J Pharmace Sci Inven, 2013; 2: 26-33.

[18] B. S. Oken, D. M. Storzbach, and J. A. Kaye, "The efficacy of Ginkgo biloba on cognitive function in Alzheimer disease". Arch Neurol, 1995; 55: 1409-14015.

[19] S. Goswami, A. Saoji, N. Kumar, V. Thawani, M. Tiwari, M. Thawani. "Effect of Bacopa monnierion cognitive functions in Alzheimer's disease patients". Int J Colla Res Int Medi Pub Heal, 2011; 3: 285-289.

[20] A. A. Skolnick. "Old Chinese herbal medicine used for fever yields possible new Alzheimer disease therapy". J Am Med Assoc, 1997; 277: 776

[21] V. Altay, I. I. Ozyigit, M. Keskin, G. Demir, I. E. Yalcin. “An ecological study of endemic plant Polygonum istanbulicum keskin and its environs". Paki J Bot, 2013; 45: 455-459.

[22] K. Uddin, A. H. M. M. Rahman, A. K. M. R. Islam. "Taxonomy and traditional medicine practices of Polygonaceae (smartweed) family at Rajshahi, Bangladesh". Int J Adv Res, 2014; 2 : 459-469.

[23] M. J. Hossen, S. C. Kim, Y. J. Son et al., "AP-1-targeting anti-inflammatory activity of the methanolic extract of Persicaria chinensis". Evi-Bas Comple Alt Medi, 2015; 2015: $1-9$.

[24] S. Schmitt-Schillig, S. Schaffer, C. C. Weber, G. P. Eckert, W. E Muller. "Flavonoids and the aging brain". J Physio Pharmacolo, 2005; 56: 23-36.

[25] A. Q. Haddad, V. Venkateswaran, L. Viswanathan, S. J. Teahan, N. E. Fleshner, L. H.Klotz. "Novel antiproliferative flavonoids induce cell cycle arrest in human prostate cancer cell lines". Prosta Canc Prosta Dise. 2006; 9: 68-76.

[26] A. S. Apu, S. H. Bhuyan, S. S. Prova, M. A. Muhit. "Anti-inflammatory activity of medicinal plants native to Bangladesh: a review". J App Pharmace Sci. 2012; 2(2): 7-10.

[27] M. Ahmed, S. K. Sadhu, B. K. Datta, J. K. Kundu, S. C. Bachar. "Preliminary studies on the antiinflammatory, analgesic and diuretic activity of stagninol, a sesquiterpene isolated from Persicaria stagnina". Die Pharmazie, 1997; 52(6): 472-475. 
[28] N. H. N. Hashim, F. Abas, K. Shaari, H. H. Lajis. "Antioxidant and xanthine oxidase inhibitory activities of Persicaria hydropiper”. Int J Food Prop, 2013; 16(5): 1028.

[29] A. K. M. M. Huq, J. A. Jamal J. Stanslas. "Ethnobotanical, phytochemical, pharmacological, and toxicological aspects of Persicaria hydropiper (L.) Delarbre". Evi-Bas Comp Alt Med, 2014; 2014: 1-11.

[30] National Research Council. "Guide for the care and use of laboratory animals". 8th ed. Washington, D.C: National Academies Press, 2011.

[31] J. B. Weon, J. Lee, M. R. Eom, Y. S. Jung, C. J. Ma. "The effects of Loranthus parasiticuson scopolamine induced memory impairment in mice". J Evi-Bas Com Alt Med, 2014; 2014: $1-7$

[32] A. K. M. Moyeenul Huq, J. A. Jamal, J. Stanslas. "Ethnobotanical, phytochemical, pharmacological, and toxicological aspects of Persicaria hydropiper (L.) Delarbre". Evi-Bas Com Alt Med, 2014 (2014): 1-5.

[33] Organisation for Economic cooperation and Development. "OECD guidelines for the testing of chemicals:acute oral toxicity - acute toxic class method". Paris: OECD Environment, Health and Safety Publications, 2002.

[34] D. S. Reddy S. K. Kulkarni. "Possible role of nitric oxide in the nootropic and antiamnesic effects of neurosteroids on agingand dizocilpine-induced learning impairment". Brain Res, 1998; 799: 215-29.

[35] Z. Hlinak I. Krejci. "MK-801 induced amnesia for the elevated plus-maze in mice". Behav Brain Rese, 2002; 131: 221-25.

[36] T. V. S. S. Swaroop, S. Banerjee and M. Handral, "Neuroprotective evaluation of leaf extract of Dalbergia sissoo in 3-nitropropionic acid induced neurotoxicity in rats". Int $\mathrm{J}$ Pharmaceu Sci Drug Res, 2014; 6: 41-47.

[37] U. D. Ozkay, O. D. Can, Y. Ozkay Y. Ozturk. "Effect of benzothiazole/piperazine derivatives on intracerebroventricularstreptozotocin-induced cognitive deficits". Pharmacol Repo, 2012; 64: 834-847.

[38] S. O. Ogren, W. S. Stone H. J. Altman. "Evidence for a functional interaction between serotonergic and cholinergic mechanisms in memory retrieval". Soci Neurosci Abs, 1985; 256: 1-11.

[39] F. J. van der Staay, T. Schuurman, C. G. Van Reenen, S. M. Korte. "Emotional reactivity and cognitive performance in aversively motivated tasks: a comparison between four rat strains". Behav Brain Fun, 2009; 5: 1-24.

[40] J. Wang, X. Wang, B. Lv, W. Yuan, Z. Feng, M. I. Weidong. "Effects of Fructus akebiae on learning and memory impairment in a scopolamine-induced animal model of dementia". Experi Therapeu Medic, 2014; 8: 671-675.

[41] R. Morris. "Developments of a water-maze procedure for studying spatial learning in the rat". J Neurosci Meth, 1984; 11: 47-60.

[42] D. Dhingra V. Kumar. "Memory-enhancing activity of Palmatine in mice using elevated plus maze and morris water maze". Adv Pharmacol Sci, 2012; 2012: 1-5.

[43] M. Taati, M. Alirezaei, M. H. Moshkatalsadat, B. Rasoulian, M.
Moghadasi F. Sheikhzadeh. "Protective effects of Ziziphus jujube fruit extract against ethanol-induced hippocampal oxidative stress and spatial memory impairment in rats". J Medi Plants Res, 2011; 5: 915-921.

[44] A. Blokland, E. Geraerts M. Been. "A detailed analysis of rats' spatial memory in a probe trial of a Morris task". Behavi Brain Res, 2004; 154: 71-75.

[45] T. Kameyama, T. Nabeshima, T. Kozawa. "Step-down-type passive avoidance- and escape-learning method. Suitability for experimental amnesia models". J Pharmacol Methods, 1986; 16: $39-5$.

[46] B. Chance, A. C. Maehly. "Assay of catalase and peroxidases". Meth in Enzymo, 1955; 11: 764-775.

[47] P. Kakkar, B. Das, P. N. Viswanathan. "A modified spectrophotometric assay of superoxide dismutase". Ind J Bioche\&Biophy, 1984; 21: 130-132.

[48] I. Carlberg, E. B. Mannervik. "Glutathione level in rat brain". J Biol Chem, 1975; 250: 4475-4480.

[49] W. H. Habig, M. J. Pabst, W. B. Jakoby. "Glutathione-S-transferases: the first enzymatic step in mercapturic acid formation”. J Bio Che, 1974; 249: 7130-7139.

[50] J. Mohandas, J. J. Marshal, G. G. Duggin, J. S. Horvath, D. J. Tiller. "Differential distribution of glutathione and glutathione-related enzymes in rabbit kidney: possible implications in analgesic nephropathy". Bioche Pharmacol, 1984; 33: 1801-1807.

[51] M. Iqbal, M. D. Sharma, H. R. Zadeh, N. Hasan, M. Abdulla, M. Athar, et al., "Glutathione metabolizing enzymes and oxidative stress in ferric nitrilotriacetate (Fe-NTA) mediated hepatic injury". Redox Repo, 1996; 2: 385-391.

[52] G. L. Ellman, K. D. Courtney, V. Andres, R. M. Featherstone, "A new and rapid colorimetric determination of acetylcholinesterase activity". Bioche Pharmacol, 1996; 7: 88-95.

[53] M. Bhaskar, M. Chintamaneni. "Investigating the role of Eclipta alba on brain antioxidant markers, cognitive performance and acetylcholinesterase activity of rats". Int $\mathrm{J}$ Pharmace Phytopharmaco Res, 2014; 3: 390-394.

[54] J. B. Weon, J. Lee, M. R. Eom, Y. S. Jung, C. J. Ma "The effects of Loranthus parasiticusonscopolamine-induced memory impairment in mice". Evi-Base Compl Alt Medi, 2014; 2014: $1-6$.

[55] A. Petkau, W. Chelack, S. Pleskach, B. Meeker, C. Brady. "Radioprotection of mice by superoxidedismutase". Bioche and Biophy Res Communi, 1975; 65: 886.

[56] M. Salin, J. McCord. "Free Radicals and Inflammation. Protection of phagocytosing leukocytes by superoxide dismutase". J ClinInvesti, 1975; 56: 1319.

[57] M. A, Ansari, S. W. Scheff. "Oxidative stress in the progression of Alzheimer Disease in the frontal cortex". J Neuropa\&Experi Neurol, 2010; 69: 155-167.

[58] V. K. Celik, E. Ersan, Ersan, S. Bak, O. Dogan. "Plasma catalase, glutathione-s-transferase and total antioxidant activity levels of children with attention deficit and hyperactivity disorder". Adv Biosci Biotech, 2013; 4: 183-187. 
[59] C. Fernandez, E. S. Miguel, A. Fernandez-briera. "Superoxide dismutase and catalase: tissue activities and relation with age in the long-lived species Margaritifera margaritifera”. Biolog Res, 2009; 42: 57-68.

[60] Y. Z. Fang, S. Yang, G. Wu. "Free radicals, antioxidants, and nutrition”. Nutri, 2000; 18: 872-879.

[61] M. Deponte, "Glutathione catalysis and the reaction mechanisms of glutathione-dependent enzymes". Biochimiet Biophysi Acta, 2013; 1830: 3217-3266.

[62] J. D. Hayes, J. U. Flanagan, I. R. Jowsey. "Glutathione transferases". Ann Rev Pharmaco Toxico, 2005; 45: 51-88.

[63] A. C. Maritim, R. A. Sanders, J. B. Watkins. "Effects of $\alpha$-lipoic acid on biomarkers of oxidative stress in streptozotocin-induced diabetic rats". J NutritiBioche, 2003; 14 : 288-294.
[64] J. A. Henning, and W. Chow. "Lipid peroxidation and endothelial cell injury: implications in atherosclerosis". Free Rad Biolo Medi, 1988; 4: 99-106.

[65] B. Halliwell, J. M. C. Gutteridge. "Role of free radicals and catalytic metal ions in human disease: an overview". Meth Enzymolo, 1990; 186: 1-85.

[66] R. A. Khan, M. R. Khan S. Sahreen. "Brain antioxidant markers, cognitive performance and acetyl cholinesterase activity of rat: Efficiency of Sonchus asper". Behav Brain Func, 2012; 8: 21 .

[67] R. A. Khan. "Effects of Launaea procumbens on brain antioxidant enzymes and cognitive performance of rat". BMC Comp Alt Medi, 2012; 12: 1. 